\title{
Delineation of groundwater potential zone: An AHP/ANP approach
}

\author{
Etishree Agarwal, Rajat Agarwal*, R D Garg and P K Garg \\ Department of Civil Engineering, Indian Institute of Technology, Roorkee 247667 , India. \\ *Corresponding author. e-mail: agarwalraja@gmail.com
}

The sustainable development and management of groundwater resource requires precise quantitative assessment based on scientific principle and modern techniques. In the present study, groundwater potential zone are delineated using remote sensing, geographical information system (GIS) and multi-criteria decision making (MCDM) techniques in Unnao district, Uttar Pradesh. The analytical network process (ANP) is a method that makes it possible for one to deal systematically, and includes the analytical hierarchy process (AHP) as a special case. The AHP and ANP are used to determine the weights of various themes and their classes for identifying the groundwater potential zone. These weights are applied in a linear combination to obtain five different groundwater potential zone in the study area, namely 'very poor', 'poor', 'moderate', 'good' and 'very good'. It has been concluded that about $153.39 \mathrm{~km}^{2}$ area has very good groundwater potential which is only $3.37 \%$ of the total study area. However, the area having very poor groundwater potential is about $850 \mathrm{~km}^{2}$ which is about $19.63 \%$ of the study area. The area having good, moderate and poor groundwater potential is about $540.25,1135.5,1868.6 \mathrm{~km}^{2}$, respectively. The groundwater potential zone map was finally verified using the well yield data of 37 pumping wells, and the result was found satisfactory.

\section{Introduction}

Groundwater has emerged as an important source to meet the water requirements of various sectors including the major consumers of water like irrigation, domestic and industries. The sustainable development of groundwater resource requires precise quantitative assessment based on reasonably valid scientific principles. Highly intensive development of groundwater in certain area of the country has resulted in over-exploitation leading to decline in groundwater levels. The estimated amount of groundwater availability for the country is 399 billion cubic meter (MOWR 2009).

With the advent of powerful and high speed computers, efficient techniques for groundwater exploration and management have evolved, of which remote sensing and GIS are of great significance (Chowdhury et al. 2009). Integration of remote sensing and GIS has proven to be an efficient tool in groundwater studies (Krishnamurthy et al. 1996). GIS is a powerful set of tool for collecting, storing, retrieving, managing and displaying spatial data into simplified form.

Two of the most important methods of MCDM are AHP and ANP. AHP proposed by Saaty (1980) as a method of solving socio-economic decision making problems has been used to solve a wide range of problems. AHP is utilized when dimensions are independent, and is suited to solving the problems involving dependent dimensions (Yang et al. 2008) while ANP also proposed by

Keywords. Groundwater; multi-criteria decision making; analytical network process. 
Saaty (1996) provides a method for input judgment and measurement to derive ratio scale priorities for the distribution of influence between the different thematic layers. Saaty (1996) suggested the use of AHP to solve the problem of independence on alternatives or criteria, and the ANP to solve the problem of dependence among alternatives or criteria (Dagdeviren and Ihsan 2007). The ANP goes beyond the AHP by including independence. It deals with dependence within a set of elements, and among different sets of elements. The looser network structure of the ANP makes it possible that the representation of any decision problem without concern for what comes first and what comes next as in a hierarchy and hence is a nonlinear structure. The ANP prioritizes not just elements but also groups or clusters of elements as is often necessary in the real world (Saaty 1999). The ANP-based system is a network that replaces single direction relationships with dependence and feedback. Therefore, ANP is more powerful than AHP in the decision environment with uncertainty and dynamics (Saaty 1996). ANP is more accurate and useful than AHP for decision making. The ANP and the AHP are based on user supplied preferences among the themes and provide utility weights for the alternatives, they differ from each other in number and types of pairwise comparisons, and also in the manner by which utility weights are actually computed (Cheng and $\mathrm{Li}$ 2004). In the changing environment with uncertainty and dynamics, the decision objectives cannot be easily identified because they correlate with other elements that also cannot be identified clearly. In this case, ANP comes to rescue (Tran et al. 2004). Therefore, ANP provides a context-specific multi-criteria evaluation method that allows for the measurement of one unique alternative in the face of general criteria (Banai 2010). The objective of this study is to delineate the groundwater potential zone using Remote Sensing, GIS and MCDM techniques and finally the results were verified using well yield data.

\section{Study area}

Unnao district is a part of central Ganga Plain of Uttar Pradesh with a geographical area of $4558 \mathrm{~km}^{2}$ which is about $1 / 10$ percent of total

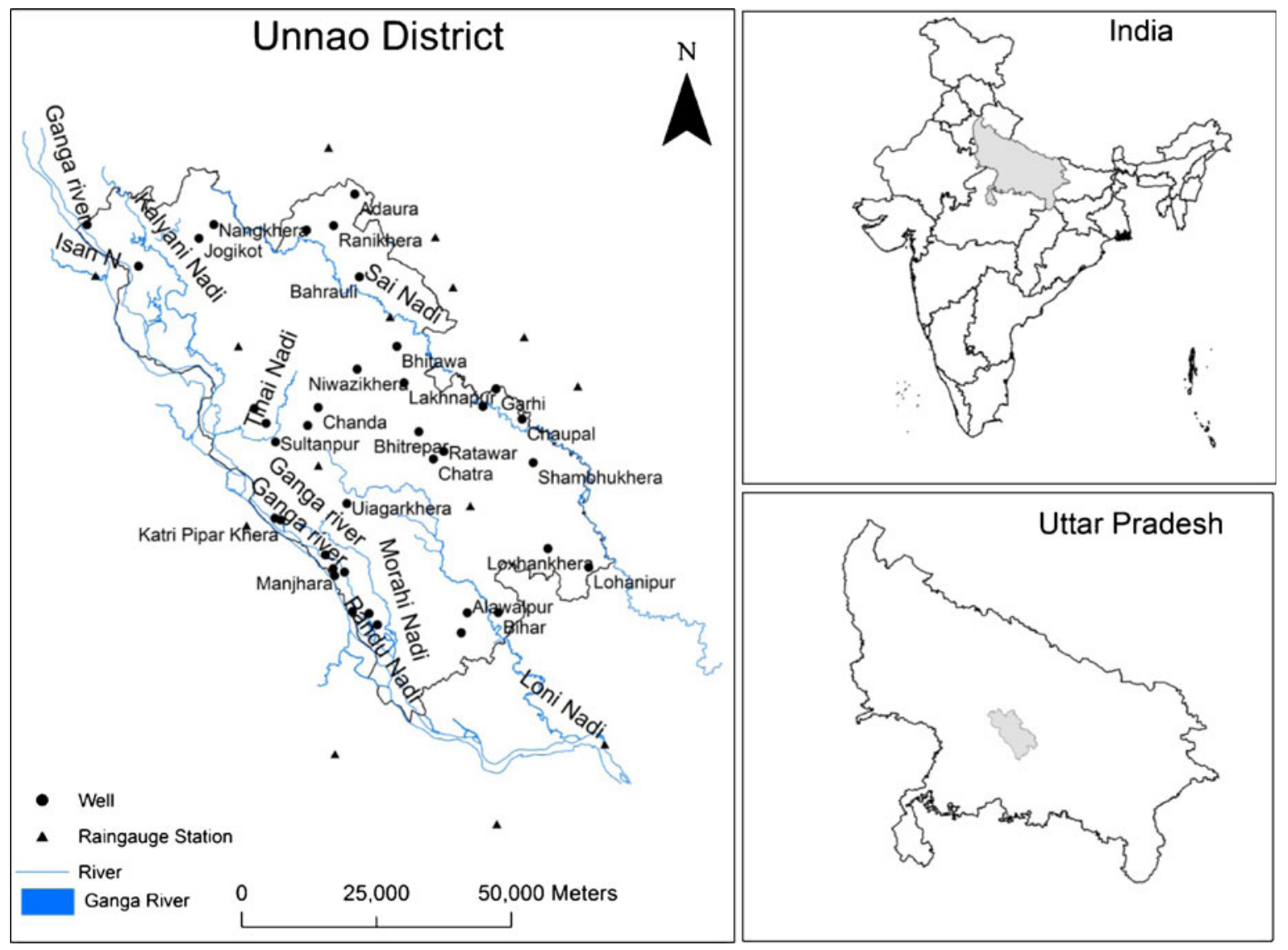

Figure 1. The study area. 
land in India. It lies between latitudes $26^{\circ} 06^{\prime}$ and $27^{\circ} 03^{\prime} \mathrm{N}$ and longitudes $80^{\circ} 03^{\prime}$ and $81^{\circ} 03^{\prime} \mathrm{E}$. The maximum temperature is $45^{\circ} \mathrm{C}$ in summer and minimum $3{ }^{\circ} \mathrm{C}$ in winter. The district receiving a normal annual rainfall of $837.80 \mathrm{~mm}$ with rainy days experiences sub-tropical climate. The district is mainly drained by river Ganga and its tributaries Kalyani, Khar, Loni and Morahi in the western part and by Sai river in the eastern part of the district, and all these rivers are perennial in nature. About $87 \%$ area of net shown area $(300,000$ hectares) is irrigated both by surface water (Sharda Canal network system) and groundwater through shallow and moderately deep tube wells. The share of surface water irrigation is $48 \%$ while that of groundwater is $52 \%$. The economy of the district mainly depends upon agriculture (figure 1).

\section{Criteria and methodology}

In this study following three steps are used to evaluate groundwater potential zone.

\subsection{Development of thematic layers}

Development of thematic layers involves digital image processing of remote sensing data, digitization of existing maps and field data for extraction of pertinent information. To identify the groundwater potential zone in the study area, thematic layers of geomorphology, geology, slope, rainfall, landuse, soil, groundwater depth, lineament and drainage density were generated using topographic maps, thematic maps, field data and satellite image in GIS environment. Initially, the satellite image of Landsat Enhanced Thematic Mapper plus (ETM+) of path-144 and row-41, 42 of imagery of $15 \mathrm{~m}$ spatial resolution pertaining to 11 October 2006 in eight spectral bands, Advanced Spaceborne Thermal Emission and Reflection Radiometer Digital Elevation Model (ASTER DEM) of 17 October 2011, Geological Survey of India (GSI) map and soil map of Unnao district are georeferenced with the help of Survey of India toposheet mosaic using the projection UTM (Universal Traverse Mercator) and datum WGS84 (World Geodetic System 84). Geology, geomorphology and lineament layers are prepared using the GSI map and further updated with satellite image. Lineament density layer is prepared using lineament layer. Drainage layer is generated from Survey of India toposheets at 1:50,000 scale. Subsequently, drainage is updated with the satellite image. Drainage density map is prepared using drainage layer. Slope map was prepared from ASTER DEM using spatial analyst tool. The soil map was generated with the aid of National Bureau of Soil Survey and Land Use Planning (NBSSLUP) map. Landuse map was generated using Landsat ETM+ image in ERDAS Imagine 9.3 software. For generation of landuse, supervised classification was performed using Bayesian Maximum Likelihood Classifier (MLC). MLC, a parametric decision rule, is a well developed method from statistical decision theory that has been applied to classifying ETM+ image. After the classification, accuracy assessment of the landuse map was substantiated by correlating ground truth information. Groundwater level data of 20 years have been acquired from State Ground Water Board (SGWB) office, Lucknow and finally groundwater depth map has been prepared using Inverse Distance Weighted interpolation technique. Daily rainfall data of 14 raingauge stations that is lying in the study area or near the study area has been acquired from India Meteorological Department, Pune. The mean annual rainfalls based on 15 years were used to create rainfall map of the study area. The complete work flow of methodology is given in figure 2 .

\subsection{Deriving the weights using AHP/ANP}

ANP is an extension of AHP for decision making in which a problem is divided into various parameters, arranging them in a hierarchical structure, making judgments on the relative importance of pairs of elements and synthesizing the results (Saaty 1999).

Each thematic layer has more than five classes, which indicates the relationships between these interrelated classes is too complex. Hence, the relationship between these nine thematic layers has been derived using ANP and relationship between their various classes has been identified using AHP. The methodology for deriving the weights to the thematic layers and their corresponding classes using ANP and AHP respectively, involves following steps:

Step 1: Construction of model: On the basis of literature review, many models have been identified for mapping groundwater potential. In the construction of model, the problem should be clearly defined and then decomposed into various thematic layers containing the different feature/classes of the individual themes so that form a network of the model.

Step 2: Generation of pairwise comparison matrices: The relative importance values are determined with Saaty's 1-9 scale (table 1), where a score of 1 represents equal importance between the two themes, and a score of 9 indicates the extreme importance of one theme compared to the other one (Saaty 1980). 


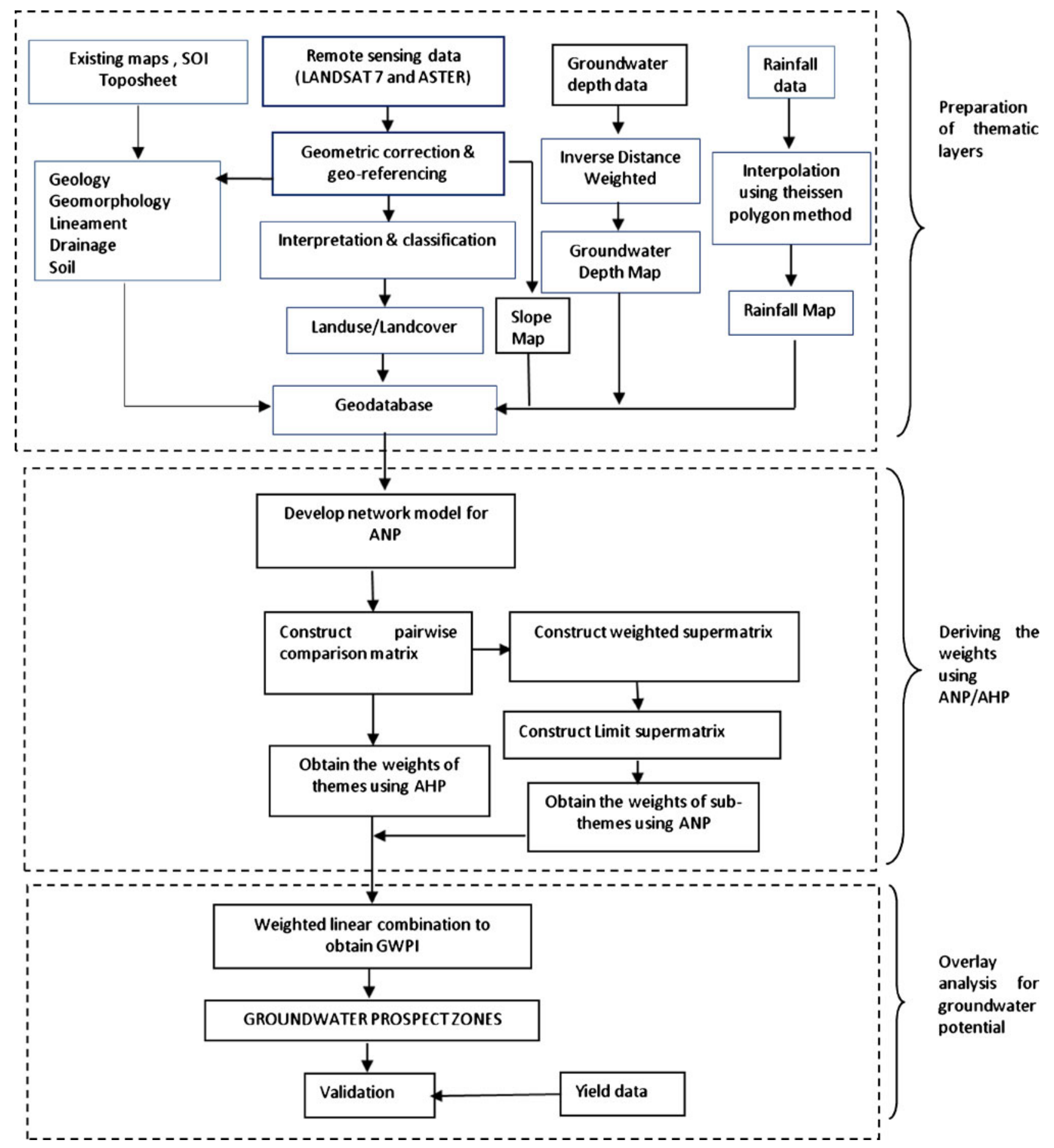

Figure 2. Flow chart of methodology used for deriving groundwater potential.

Table 2 shows a matrix for comparing the classes in order to achieve the priority. A pairwise comparison matrix is derived using Saaty's nine-point importance scale based on thematic layers used for delineation of groundwater potential. The AHP captures the idea of uncertainty in judgements through the principal eigenvalue and the consistency index (Saaty 2004). Saaty gave a measure of consistency, called Consistency Index (CI) as deviation or degree of consistency using the following equation (1):

$$
C I=\frac{\lambda_{\max }-n}{n-1}
$$

where $\lambda_{\max }$ is the largest eigenvalue of the pairwise comparison matrix and $n$ is the number of classes. Consistency Ratio $(C R)$ is a measure of 
Table 1. Saaty's 1-9 scale of relative importance.

\begin{tabular}{lccccccccc}
\hline Scale & 1 & 2 & 3 & 4 & 5 & 6 & 7 & 8 & 9 \\
\hline Importance & $\begin{array}{c}\text { Equal } \\
\text { importance }\end{array}$ & Weak & $\begin{array}{c}\text { Moderate } \\
\text { importance }\end{array}$ & $\begin{array}{c}\text { Moderate } \\
\text { plus }\end{array}$ & $\begin{array}{c}\text { Strong } \\
\text { importance }\end{array}$ & $\begin{array}{c}\text { Strong } \\
\text { plus }\end{array}$ & $\begin{array}{c}\text { Very strong } \\
\text { importance }\end{array}$ & $\begin{array}{c}\text { Very, very } \\
\text { strong }\end{array}$ & $\begin{array}{c}\text { Extreme } \\
\text { importance }\end{array}$ \\
\hline
\end{tabular}

Table 2. Pairwise comparison matrix.

\begin{tabular}{|c|c|c|c|c|c|c|c|c|c|}
\hline & $\begin{array}{c}\text { Drainage } \\
\text { density }\end{array}$ & $\begin{array}{c}\text { Groundwater } \\
\text { depth }\end{array}$ & Geomorphology & Soil & Landuse & Geology & Rainfall & Slope & Lineament \\
\hline Drainage density & 1 & $1 / 3$ & $1 / 4$ & 3 & 6 & $1 / 2$ & 4 & 5 & 2 \\
\hline Groundwater depth & 3 & 1 & $1 / 2$ & 5 & 8 & 2 & 6 & 7 & 4 \\
\hline Geomorphology & 4 & 2 & 1 & 6 & 9 & 3 & 7 & 8 & 5 \\
\hline Soil & $1 / 3$ & $1 / 5$ & $1 / 6$ & 1 & 4 & $1 / 4$ & 2 & 3 & $1 / 2$ \\
\hline Landuse & $1 / 6$ & $1 / 8$ & $1 / 9$ & $1 / 4$ & 1 & $1 / 7$ & $1 / 3$ & $1 / 2$ & $1 / 5$ \\
\hline Geology & 2 & $1 / 2$ & $1 / 3$ & 4 & 7 & 1 & 5 & 6 & 3 \\
\hline Rainfall & $1 / 4$ & $1 / 6$ & $1 / 7$ & $1 / 2$ & 3 & $1 / 5$ & 1 & 2 & $1 / 3$ \\
\hline Slope & $1 / 5$ & $1 / 7$ & $1 / 8$ & $1 / 3$ & 2 & $1 / 6$ & $1 / 2$ & 1 & $1 / 4$ \\
\hline Lineament & $1 / 2$ & $1 / 4$ & $1 / 5$ & 2 & 5 & $1 / 3$ & 3 & 4 & 1 \\
\hline
\end{tabular}

Table 3. Saaty's ratio index for different values of $n$.

\begin{tabular}{ccccccccccc}
\hline$n$ & 1 & 2 & 3 & 4 & 5 & 6 & 7 & 8 & 9 & 10 \\
\hline$R I$ & 0 & 0 & 0.58 & 0.89 & 1.12 & 1.24 & 1.32 & 1.41 & 1.45 & 1.49 \\
\hline
\end{tabular}

Table 4. Weighted supermatrix.

\begin{tabular}{lcccccccccc}
\hline & $\begin{array}{c}\text { Drainage } \\
\text { Parameters }\end{array}$ & Groundwater & & & & & & & & \\
depth & Geomorphology & Soil & Landuse & Geology & Rainfall & Slope & Lineament \\
\hline Drainage density & 0.10518 & 0.12041 & 0.1161 & 0.10113 & 0.12596 & 0.08507 & 0.09323 & 0.11295 & 0.10518 \\
Groundwater depth & 0.25168 & 0.21724 & 0.23935 & 0.24872 & 0.28375 & 0.25504 & 0.30962 & 0.21506 & 0.25708 \\
Geomorphology & 0.32826 & 0.26682 & 0.29756 & 0.35463 & 0.25811 & 0.30526 & 0.26033 & 0.32905 & 0.30717 \\
Soil & 0.04235 & 0.05996 & 0.04707 & 0.03878 & 0.0995 & 0.04598 & 0.04571 & 0.04382 & 0.05461 \\
Landuse & 0.01278 & 0.02074 & 0.01348 & 0.01519 & 0.01324 & 0.01642 & 0.01737 & 0.01793 & 0.01769 \\
Geology & 0.15264 & 0.14423 & 0.16702 & 0.13872 & 0.10148 & 0.16884 & 0.15072 & 0.15485 & 0.11717 \\
Rainfall & 0.02682 & 0.04054 & 0.03076 & 0.02745 & 0.02963 & 0.02971 & 0.03239 & 0.03167 & 0.03848 \\
Slope & 0.01812 & 0.02857 & 0.01856 & 0.01952 & 0.02054 & 0.02098 & 0.02274 & 0.02267 & 0.03132 \\
Lineament & 0.06216 & 0.1015 & 0.07011 & 0.05587 & 0.0678 & 0.07269 & 0.06789 & 0.072 & 0.0713 \\
\hline
\end{tabular}

Table 5. Limit supermatrix.

\begin{tabular}{llccccccccc}
\hline & $\begin{array}{c}\text { Drainage } \\
\text { Parameters }\end{array}$ & $\begin{array}{c}\text { Groundwater } \\
\text { density }\end{array}$ & depth & Geomorphology & Soil & Landuse & Geology & Rainfall & Slope & Lineament \\
\hline Drainage density & 0.10895 & 0.10895 & 0.10895 & 0.10895 & 0.10895 & 0.10895 & 0.10895 & 0.10895 & 0.10895 \\
Groundwater depth & 0.24206 & 0.24206 & 0.24206 & 0.24206 & 0.24206 & 0.24206 & 0.24206 & 0.24206 & 0.24206 \\
Geomorphology & 0.2971 & 0.2971 & 0.2971 & 0.2971 & 0.2971 & 0.2971 & 0.2971 & 0.2971 & 0.2971 \\
Soil & 0.0504 & 0.0504 & 0.0504 & 0.0504 & 0.0504 & 0.0504 & 0.0504 & 0.0504 & 0.0504 \\
Landuse & 0.01624 & 0.01624 & 0.01624 & 0.01624 & 0.01624 & 0.01624 & 0.01624 & 0.01624 & 0.01624 \\
Geology & 0.15309 & 0.15309 & 0.15309 & 0.15309 & 0.15309 & 0.15309 & 0.15309 & 0.15309 & 0.15309 \\
Rainfall & 0.03302 & 0.03302 & 0.03302 & 0.03302 & 0.03302 & 0.03302 & 0.03302 & 0.03302 & 0.03302 \\
Slope & 0.0226 & 0.0226 & 0.0226 & 0.0226 & 0.0226 & 0.0226 & 0.0226 & 0.0226 & 0.0226 \\
Lineament & 0.07654 & 0.07654 & 0.07654 & 0.07654 & 0.07654 & 0.07654 & 0.07654 & 0.07654 & 0.07654 \\
\hline
\end{tabular}


consistency of pairwise comparison matrix and is given by equation (2)

$$
C R=\frac{C I}{R I}
$$

where $R I$ is the Ratio Index. The value of $R I$ for different $n$ values is given in table 3 .

If the value of $C R$ is smaller or equal to 0.1 , the inconsistency is acceptable. If $C R$ is greater than $10 \%$, we need to revise the subjective judgement. $C R$ of the pairwise comparison matrix shown in table 2 is 0.04 . The weights of the detailed criteria or classes and their $C R$ are shown in table 6 .

Step 3: Constructing the supermatrix of the ANP: After obtaining the pairwise comparison matrix, supermatrix of the ANP model is constructed to represent the relative priority of elements. The original supermatrix of column eigenvectors is obtained from pairwise comparison matrices of elements. Let us consider a system of $n$ components, and each of the components has an impact or influenced by some or all of the elements in that or another component with respect to the property governing the interaction of the entire system. Let the component of a decision system denoted by $C_{k}, k=$ $1,2, \ldots, n$. For each component, there exist $m_{k}$ elements denoted as $e_{k 1}, e_{k 2}, \ldots, e_{k m k}$. Now, the impact of $C_{k}$ can be denoted as follows:

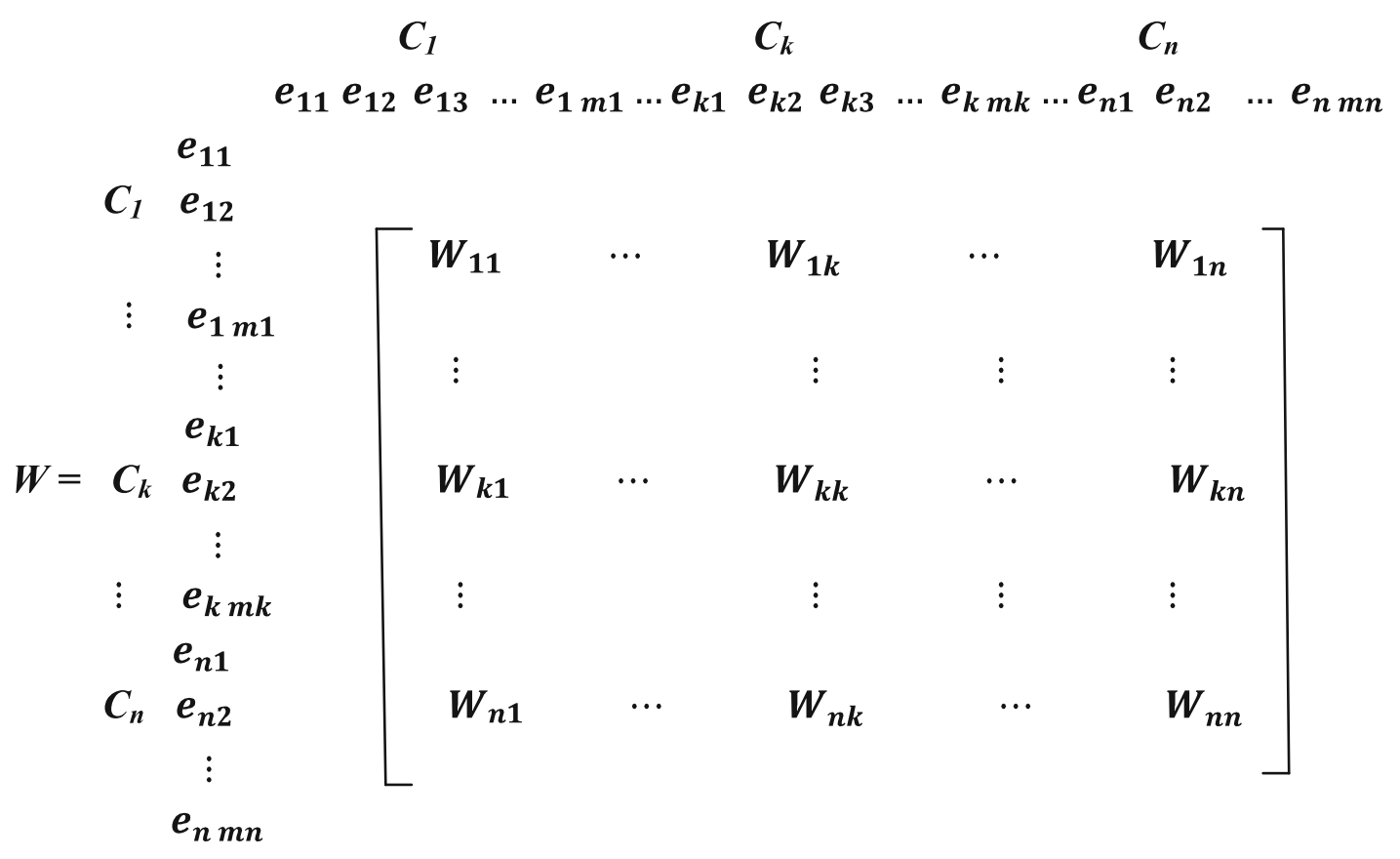

The local priority vectors are entered in the appropriate columns of the supermatrix to obtain the relative priorities of various classes with interdependent influences. A supermatrix is a partitioned matrix, where each matrix segment represents a relationship between two clusters (Sun et al. 2007; Wang et al. 2009). To obtain the weighted supermatrix (table 4), each column of the supermatrix is weighted by multiplying the corresponding weights and normalized. To determine the final relative priorities, the limit supermatrix is obtained by raising the weighted supermatrix to powers by multiplying by itself. When each row of the supermatrix becomes equal, the limit supermatrix has been reached, as shown in table 5 .

\section{Overlay analysis to find groundwater potential zone}

The groundwater potential index (GWPI) is computed by the weighted linear combination method (Malczewski 1999; Machiwal et al. 2011) is given by

$$
\mathrm{GWPI}=\sum_{i=1}^{n} \sum_{j=1}^{m}\left[\alpha_{i}\left(\beta_{i j} x_{i j}\right)\right]
$$

where $\beta_{i j}=$ weight of the $j$ th class of $i$ th theme obtained by AHP and $\alpha_{i}=$ weight of the $i$ th theme obtained by ANP, $n=$ total number of thematic layers, and $m=$ total number of classes in a thematic layer, $x_{i j}$ is the pixel value of the $j$ th class of the $i$ th theme. 
Output map of groundwater potential is validated by well yield data of the study area, as shown in figure 5. Groundwater prospects of the various villages are compared with the yield data.

\section{Ranking classes of various parameters}

The occurrence and movement of groundwater in an area is governed by several layers, such as topography, geology, geomorphology, structure, landuse, soil, rainfall, drainage density, groundwater depth and interrelationship between these layers (Jaiswal et al. 2003).

\subsection{Geology}

Geologically, the area has been divided into various classes, i.e., channel alluvium, terrance alluvium, lacustrine deposits and older alluvium. Channel alluvium is micaceous; fine to grained medium consists of gravel, loose sand, slit and clay and has better productivity due to presence of water in sand and gravel beds, so it is given higher preference in determining the groundwater potential.

\subsection{Geomorphology}

The landform plays a vital role for the occurrence and distribution of groundwater. Four types of geomorphic units are identified in the study area. Active flood plain has higher water level surface, and hence it is the best landform for high groundwater potential.

\subsection{Landuse}

Landuse are interpretable by satellite images. Various types of landuse pattern are identified in the study area which includes vegetation, sandy area, fallow land, water body, wasteland and urban area. Vegetation are excellent sites for groundwater exploration, and hence given the highest rank. Sandy areas are considered to have good groundwater prospects, while the water bodies and urban area have poor groundwater potential.

\subsection{Drainage density}

Drainage density is an inverse function of permeability, and therefore it is an important parameter in evaluating the groundwater zone. High drainage density values are favourable for run-off, and hence indicates low groundwater potential zone. High ranks are assigning to low drainage density area and vice versa.

\subsection{Slope}

The slope of the study area mainly varies between zero and 5\%. Class having less value is assigned higher rank due to almost flat terrain while the class having maximum value is categorized as lower rank due to relatively high run-off.

\subsection{Soil}

The soil for the study area reveals four main soil categories namely sandy, sandy loam, silt loam and clay. Rank of soil has been assigned on the basis of their infiltration rate. Sandy soil has high infiltration rate, hence given higher priority, while the clayey soil has least infiltration rate hence assigned low priority.

\subsection{Rainfall}

Rainfall is the major source of recharge. It determines the amount of water that would be available to percolate into the groundwater system. The rainfall map was grouped into four classes which are $<250 ; 250-500 ; 500-750$ and $>750 \mathrm{~mm} /$ year. It is observed that northern and eastern parts of the area receive the largest amount of rainfall while the southern part receives the lowest amount of rainfall. High rainfall is favourable for high groundwater potential, hence assigned higher priority.

\subsection{Lineament}

Structures are the rock failure and deformation created by the changes in stress with time. Lineaments, faults and fractures are the important linear structures for increasing the permeability of the bed rock. The geologically core area is subdivided by straight long fractures, called lineament. Lineament is an important layer in determining the groundwater potential as it indirectly provides the information about the movement and storage of groundwater.

\subsection{Average pre- and post-monsoon groundwater depth}

Contour maps of pre-monsoon and post-monsoon season have been prepared from groundwater level data, collected from SGWB Lucknow. In premonsoon season (figure 3), average groundwater depth generally ranges from 1.97 to $15.4 \mathrm{~m}$, with a major portion of the area having $2-5.5 \mathrm{~m}$ depth. In the western part of the area, groundwater depth is 9-15.4 m. On the other hand, in the post-monsoon season (figure 3), groundwater depth ranges from 

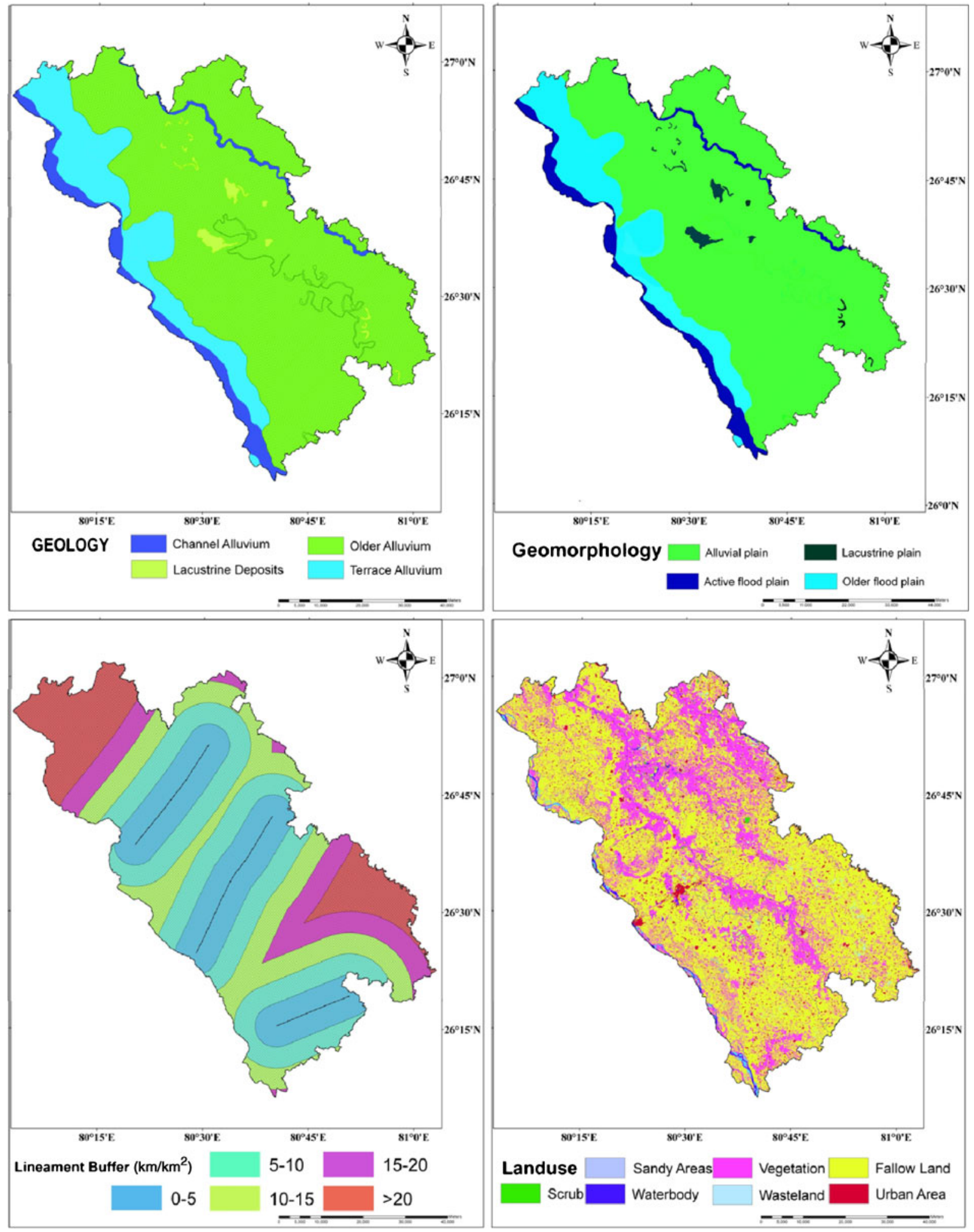

Figure 3. Classified thematic maps.

1 to $14.6 \mathrm{~m}$, with a majority of the study area having 4.5-8 $\mathrm{m}$ depth. The developed groundwater level maps are classified into four classes. On the basis of pre- and post-monsoon PCA analysis, we found that post-monsoon groundwater depth data is more suitable for analysis; it has been considered as one layer in groundwater potential mapping. 

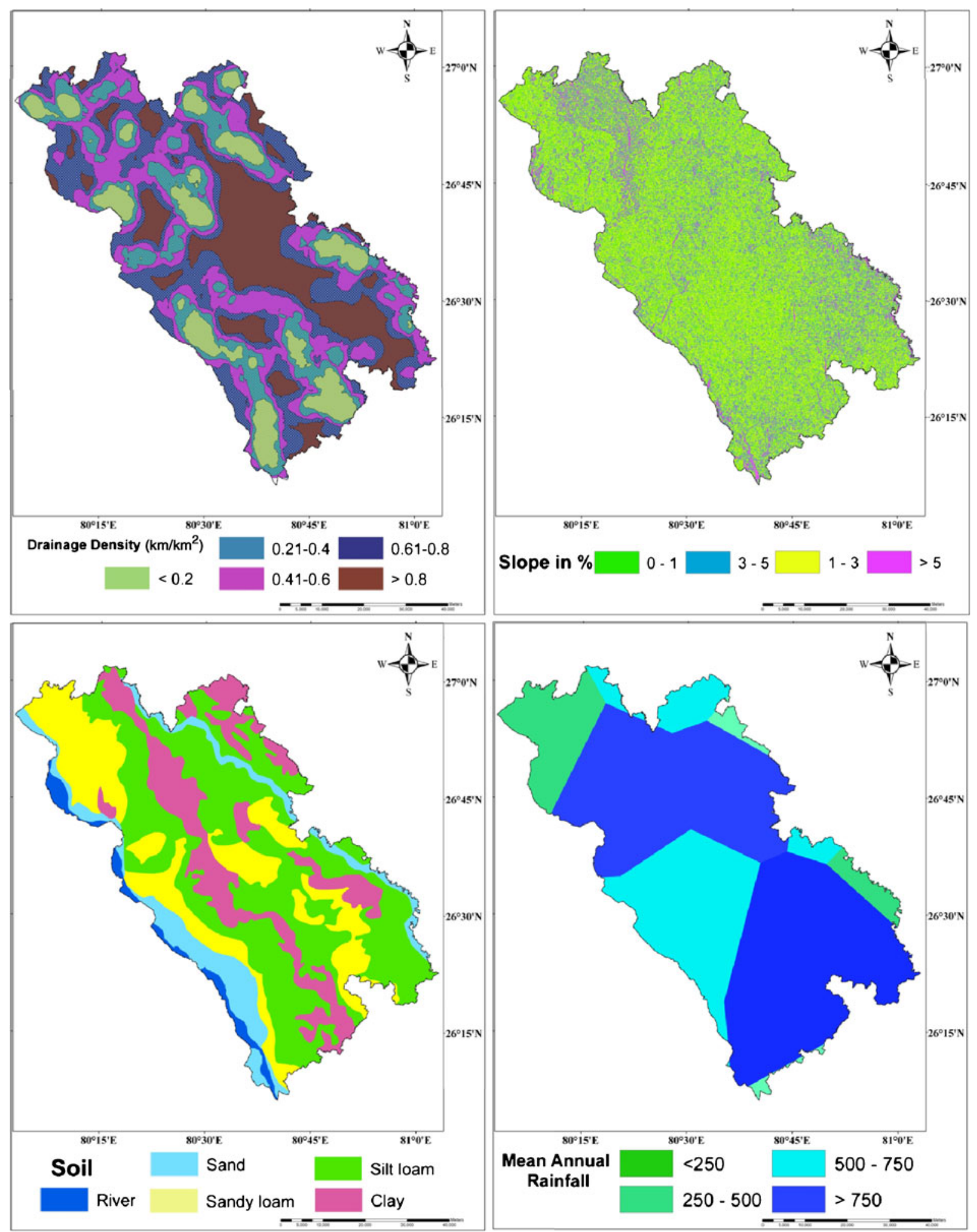

Figure 3. (Continued)

\section{Results and discussion}

In this study, an AHP/ANP based methodology that supports the relative importance of various thematic layers and their corresponding classes affecting groundwater, has been used to evaluate groundwater potential zone. Table 6 represents the weight of each thematic layer using ANP and weights of their corresponding classes using AHP. The groundwater potential evaluated by the weighted linear combination of these weights is shown in figure 4. Results indicated that only 


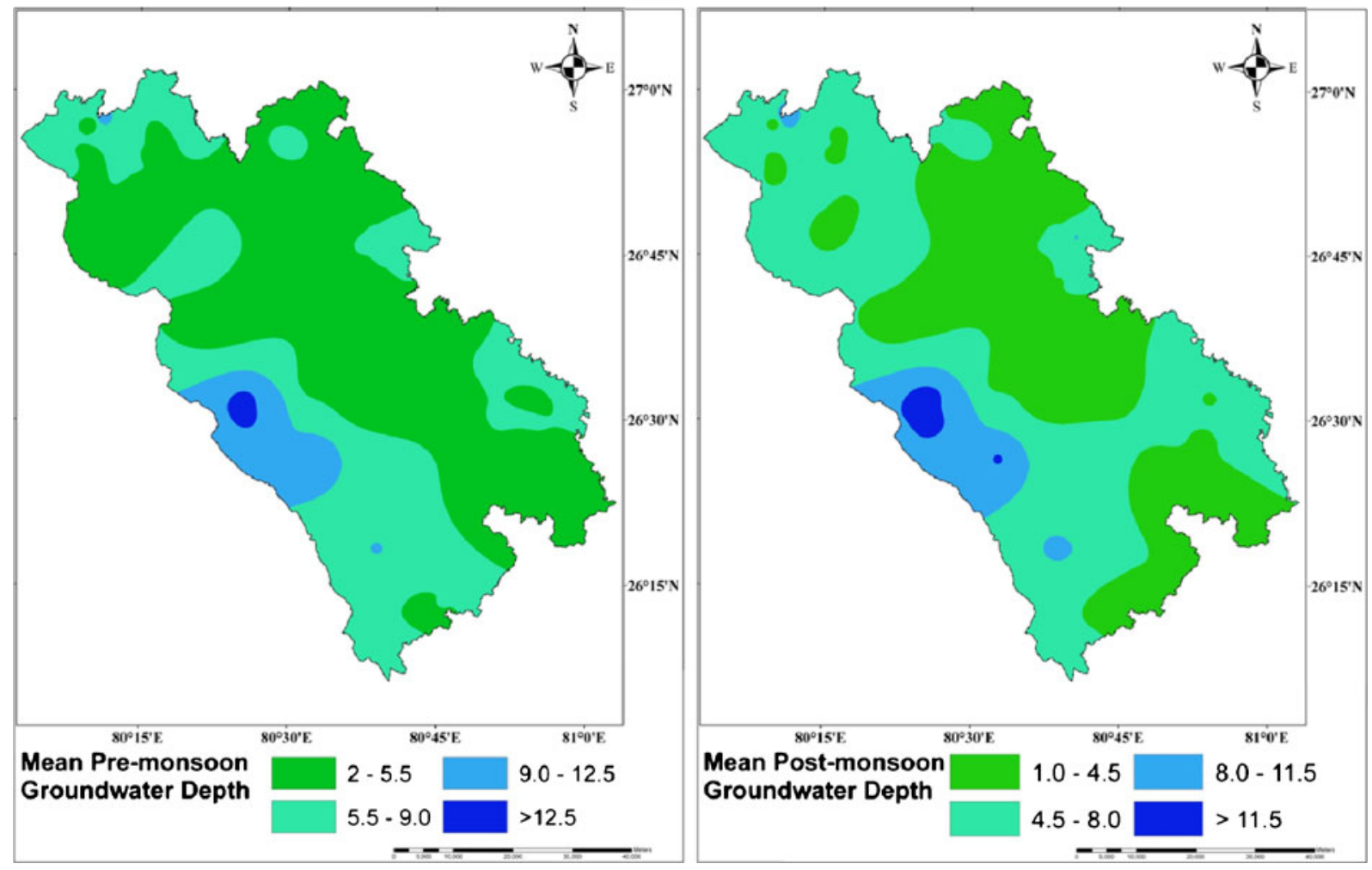

Figure 3. (Continued)

Table 6. Relative weight of various thematic layers and their corresponding classes.

\begin{tabular}{|c|c|c|c|c|c|c|c|}
\hline \multirow{2}{*}{$\frac{\text { Themes }}{\text { Geology }}$} & \multicolumn{6}{|c|}{ Various classes } & \multirow{2}{*}{$\frac{\mathrm{CR} / \text { weights }}{0.04 / 15.31}$} \\
\hline & $\begin{array}{l}\text { Channel } \\
\text { alluvium }\end{array}$ & $\begin{array}{l}\text { Terrace } \\
\text { alluvium }\end{array}$ & $\begin{array}{l}\text { Older } \\
\text { alluvium }\end{array}$ & $\begin{array}{l}\text { Lacustrine } \\
\text { deposits }\end{array}$ & - & - & \\
\hline Weight & 56.50 & 26.22 & 11.75 & 5.53 & - & - & \\
\hline Geomorphorphology & $\begin{array}{l}\text { Active flood } \\
\text { plain }\end{array}$ & $\begin{array}{l}\text { Older flood } \\
\text { plain }\end{array}$ & $\begin{array}{l}\text { Alluvial } \\
\text { plain }\end{array}$ & $\begin{array}{l}\text { Lacustrine } \\
\text { plain }\end{array}$ & - & - & $0.00 / 29.71$ \\
\hline Weight & 51.32 & 27.51 & 13.76 & 7.41 & - & - & \\
\hline Lineament buffer $\left(\mathrm{km} / \mathrm{km}^{2}\right)$ & $0-5$ & $5-10$ & $10-15$ & $15-20$ & $>20$ & - & $0.05 / 7.65$ \\
\hline Weight & 51.28 & 26.15 & 12.90 & 6.34 & 3.33 & & \\
\hline Drainage density $\left(\mathrm{km} / \mathrm{km}^{2}\right)$ & $<0.2$ & $0.21-0.4$ & $0.41-0.6$ & $0.61-0.8$ & $>0.8$ & - & $0.01 / 10.89$ \\
\hline Weight & 47.10 & 26.77 & 14.25 & 5.72 & 4.37 & - & \\
\hline Slope (\%) & $0-1$ & $1-3$ & $3-5$ & $>5$ & - & - & $0.01 / 2.26$ \\
\hline Weight & 46.73 & 27.72 & 16.01 & 9.54 & - & - & \\
\hline Rainfall (mm) & $<250$ & $250-500$ & $500-750$ & $>750$ & - & - & $0.01 / 3.31$ \\
\hline Weight & 5.53 & 11.75 & 26.22 & 56.50 & - & - & \\
\hline Soil & Sand & Sandy loam & Silt loam & Clay & & & $0.06 / 5.04$ \\
\hline Weight & 56.50 & 26.22 & 11.75 & 5.53 & - & - & \\
\hline Landuse & Vegetation & Sandy area & Fallow land & Wasteland & Waterbody & Urban area & $0.04 / 1.62$ \\
\hline Weight & 34.01 & 16.59 & 8.49 & 4.42 & 3.401 & 2.48 & \\
\hline $\begin{array}{l}\text { Mean post-monsoon } \\
\text { groundwater depth }(\mathrm{m})\end{array}$ & $1-4.5$ & $4.5-8.0$ & $8.0-11.5$ & $>11.5$ & & & $0.03 / 24.21$ \\
\hline Weight & 38.32 & 32.78 & 20.96 & 7.94 & & & \\
\hline
\end{tabular}

$3.37 \%$ of the area was classified to have very good groundwater potential and $11.9 \%$ of the area was classified as good groundwater potential, with over $24.95 \%$ being moderate and $40.15 \%$ area is poor.
$19.63 \%$ of the area is of very poor groundwater potential. Validation of groundwater potential zone with yield data at various locations is shown in figure 5. Thus the above study has demonstrated 
the capabilities of remote sensing and GIS employing MCDM techniques for the identification of groundwater potential zone. Finally, the graph showing the cumulative frequencies of the wells falling in individual groundwater potential zone

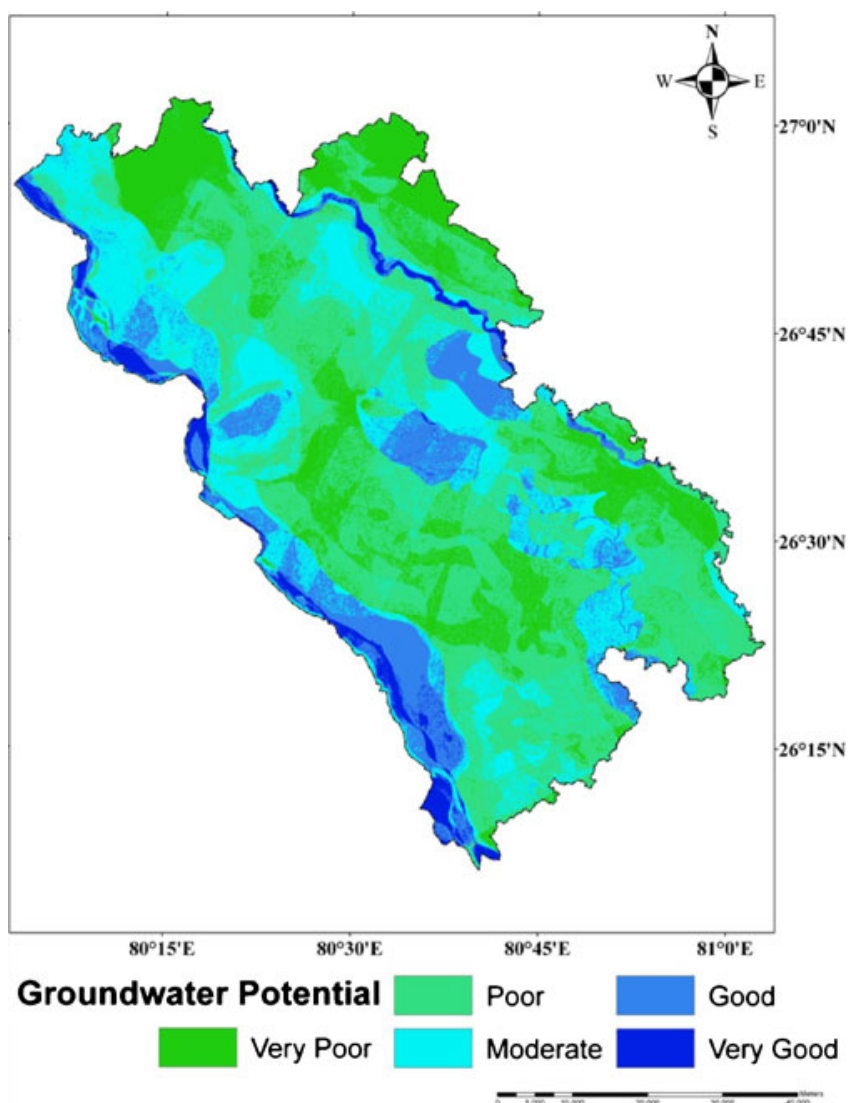

Figure 4. Groundwater potential zone map. were used for further verification. The wells having 'very good' groundwater potential zone has higher cumulative frequency than the wells falling in 'good' groundwater potential zone. Similarly, the cumulative frequency of the wells falling in 'very poor' zone is lower than that of wells having 'moderate' and 'poor' groundwater potential. This gives more realistic groundwater potential map of the study area which is used for sustainable development of groundwater resource management. Based on the result of the study, concerned decision makers can formulate an efficient groundwater utilization plan for the study area.

\section{Conclusion}

In this study, Remote Sensing, GIS and MCDM techniques have been successfully used and demonstrated for evaluation of groundwater potential zone. A three-step methodology was used that includes development of thematic layers, deriving the weights using ANP/AHP and overlay analysis to find groundwater potential zone. Remotely sensed satellite image data and digitization of existing maps using GIS were used for the preparation of thematic layers. The ANP and the AHP were used to provide utility weights for the alternatives. The overlay analysis of various thematic maps and assign weights are used for the delineation of zone of groundwater potential. In this study area, five categories of groundwater potential zone have been delineated based on remote sensing, GIS and AHP/ANP techniques.

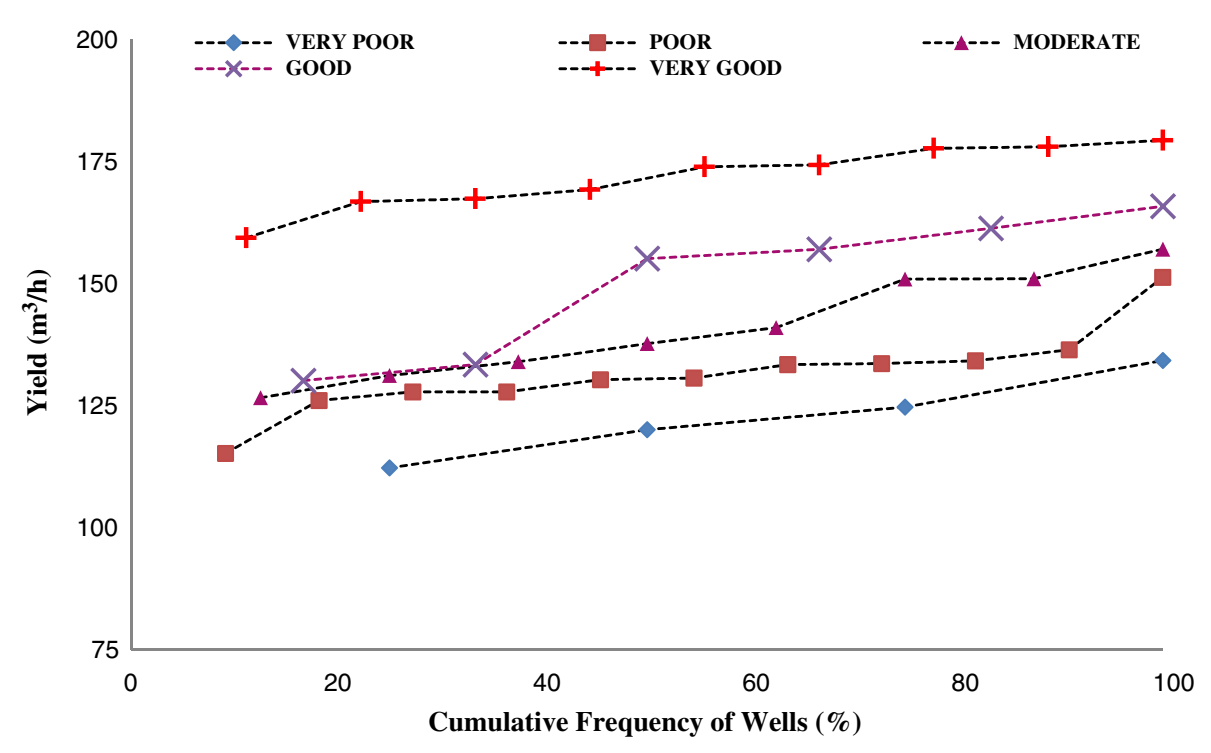

Figure 5. Cumulative frequency of wells in delineated groundwater potential zones. 


\section{References}

Banai R 2010 Evaluation of land use - transportation systems with the analytic network process; Journal of Transport and Land Use 3(1) 85-112.

Cheng E W L and Li H 2004 Contractor selection using the analytic network process; Construction Management and Economics 22 1021-1032.

Chowdhury A, Jha M K, Chowdhary V M and Mal B C 2009 Integrated remote sensing and GIS-based approach for accessing groundwater potential in west Medinipur district, West Bengal, India; Int. J. Remote Sens. 30(1) 231-250.

Dagdeviren M and Ihsan Y 2007 Personnel selection using analytic network process; Istanbul Ticaret Üniversitesi Fen Bilimleri Dergisi Yil 6(11) 99-118.

Jaiswal R, Mukherjee S, Krishnamurthy J and Saxena R 2003 Role of remote sensing and GIS techniques for generation of groundwater prospect zone towards rural development - an approach; Int. J. Remote Sens. 24(5) 993-108.

Krishnamurthy J, Kumar N V, Jayaraman V and Manivel M 1996 An approach to demarcate groundwater potential zone through remote sensing and a geographic information system; Int. J. Remote Sens. 17(10) 18671884 .

Machiwal D, Jha M K and Mal B C 2011 Assessment of groundwater potential in a semi-arid region of India using remote sensing, GIS and MCDM techniques; J. Water Resourc. Manag. 25(5) 1359-1386.

Malczewski J 1999 GIS and multicriteria decision analysis (New York: John Wiley \& Sons), 392p.
MOWR 2009 Report of the Groundwater Resource Estimation Committee; Ministry of Water Resources, Government of India, New Delhi, http://www.cgwb.gov.in.

Saaty T L 1980 The Analytic Hierarchy Process; McGrawHill, New York, NY.

Saaty T L 1996 Decision making with dependence and feedback, The Analytic Network Process; RWS Publications, Pittsburgh.

Saaty T L 1999 Fundamentals of the analytic network process; International Symposium of the Analytic Hierarchy Process (ISAHP), Kobe, Japan.

Saaty T L 2004 Fundamentals of the analytic network process - multiple networks with benefits, costs, opportunities and risks; J. Systems Science and Systems Engineering 13(3) 348-379.

Sun H, Xu G and Tian P 2007 Design alternatives evaluation of emergency bridge by applying analytic network process (ANP); System Engineering Theory and Practice 27(3) $63-70$.

Tran L T, Knight C G, O'Neill R V and Smith E R 2004 Integrated environmental assessment of the Mid-Atlantic Region with Analytical Network Process; Environmental Monitoring and Assessment, Kluwer Academic Publishers $94263-277$.

Wang Ru-Hang, Huang Jian-Guo and Zhang Qun-Fei 2009 Underwater multiple target tracking decision making based on an analytic network process; Journal of Marine Science Application 8(4) 305-310.

Yang C L, Chuang S P, Huang R H and Tai C C 2008 Location selection based on AHP/ANP approach; IEEE, International Conference on Industrial Engineering and Engineering Management, Singapore, pp. 1148-1153. 